Maximilian Hoor

\title{
TECHNOMUSEUM Landesmuseum für Technik und Arbeit in Mannheim (ed.), 2 Räder - 200 Jahre. Freiherr von Drais und die Geschichte des Fahrrades
}

[2 wheels - 200 years. Freiherr von Drais and the history of the bicycle]

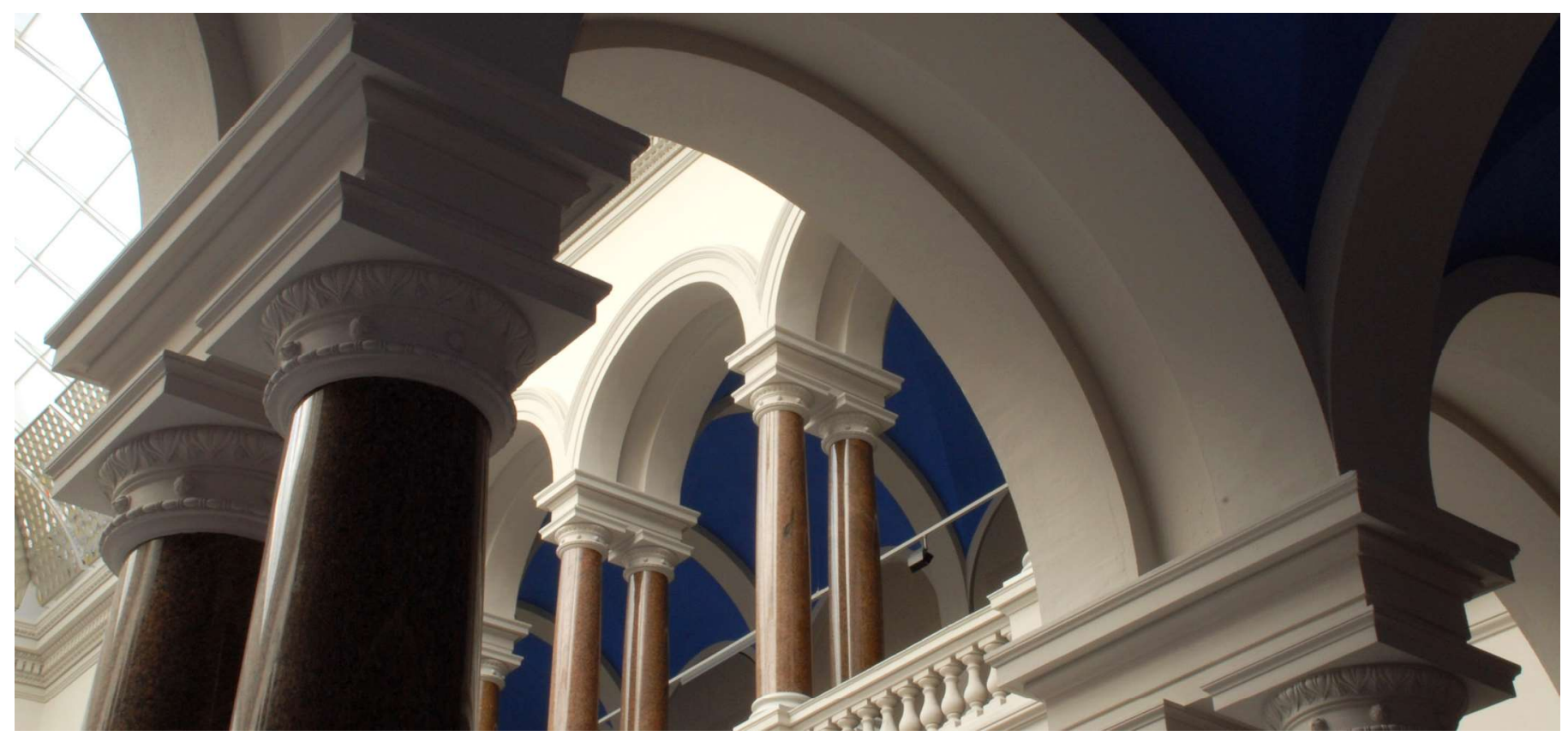

Hoor, M. (2019). TECHNOMUSEUM Landesmuseum für Technik und Arbeit in Mannheim (ed.), 2 Räder 200 Jahre. Freiherr von Drais und die Geschichte des Fahrrades [2 Wheels - 200 Years. Freiherr von Drais and the History of the Bicycle. The Journal of Transport History, 40(2), 283-284. Copyright (c) 2019 SAGE https://doi.org/10.1177/0022526619834259 
TECHNOMUSEUM Landesmuseum für Technik und Arbeit in Mannheim (ed.), 2 Räder - 200 Jahre. Freiherr von Drais und die Geschichte des Fahrrades [2Wheels-200 Years. Freiherr von Drais and the History of the Bicycle] (Darmstadt, Theiss Verlag/Wissenschaftliche Buchgesellschaft, 2016), 322 pp., 29,95€, ISBN 978-3-80623374-2

Reviewed by: Maximilian Hoor, Technische Universität Berlin, Germany

In 1817 Karl Freiherr von Drais invented a two wheeled Laufmaschine (Draisine or Velocipede) and took it for a ride around Mannheim. On the occasion of its 200-year anniversary, Germany and especially the region of Baden-Wuerttemberg, where Mannheim is located, celebrate Freiherr von Drais's invention as well as the volatile history and development of the bicycle with exhibitions, ceremonies, conferences and more. This book is the catalogue for the exhibition at the TECHNOMUSEUM Landesmuseum für Technik und Arbeit in Mannheim. This is important, because the whole structure of the book, as well as its content is pretty much tailored to accompany the display. The catalogue is published in German language only.

The book consists of four introductory greetings and essays by local politicians, as well as the director and curator of the exhibition. The text section features thirteen essays covering diverse themes such as the physics of cycling, the history of its technical development and sociocultural embeddedness, as well as more recent themes such as urban cycling lifestyles and politics. Most essays feature well picked graphics such as historical documents, technical drawings or photographs which serve as playful yet valuable illustrations. After the texts follows the plate section of the catalogue with over one hundred pages of photographs of bicycles from different eras as well as cultural artifacts such as enamel signs or posters.

The plate section is divided into four chronological chapters following the structure of the exhibition. The themes reach from the development of technical features and the production processes, to people using bicycles, its shifting cultural meaning and nowadays role in transportation planning. In contrast, although covering similar themes and questions, the main essays are not arranged in any particular chronological or thematic order, sometimes producing harsh shifts for the reader. For example, the first essay by Hans Rudolf Zeller explains in detail and disciplinal rigor the physics of cycling, using lots of technical terms, graphics and formulas that only experts will fully understand. The next essay by Hans-Erhard Lessing is an appreciation of the invention of the two-wheeled vehicle by Drais. While both essays are academic in style, they seem to address readers with very different backgrounds. Readers interested in transport history will certainly enjoy parts of the book, for example an 
essay about bicycle thefts in post-war Germany, producing unexpected and rare insights into what might otherwise be considered merely a side note; or a detailed and well illustrated essay about the shifting mode of bicycle production in the $19^{\text {th }}$ century.

Nevertheless, in this publication, brief introductions and detailed analyses, as well as thematic contents sometimes clash. This shift in content and style is the biggest reservation I have towards the book: It is not entirely clear which perspective or audience it caters for. Is this a read for the layman but overall interested? Or for academia in different disciplines, or even students? Some of the essays clearly make a valuable contribution to academic knowledge, not only in transport history, and might well be used by researchers and students due to their complex but understandable line of arguments and detailed references. Other essays are more or less based on newspaper articles and stereotypes, while others are interesting reads but lack any references at all and some others sound like variations of PR booklets from business ventures and city development strategies that have been published many times before. This may well be justified, and certainly some readers will enjoy these texts too. But the composition of the book produces disunity in style, topic and detail which makes the collection of essays less useful for academic use, which, to be fair, is probably not the main goal of the book to begin with. This indecisiveness becomes apparent in the lack of references between the essays and within the catalogue as a whole, while in fact there could be numerous relations and possible connections to draw a red line.

Altogether, the book provides a good, informative, educational and sometimes academic read to almost every possible type of reader. It is quite likely that scholars of transport history will enjoy some of the essays, while they will have problems understanding others and might even be upset by a few. Readers need to either precisely know what they are looking for, or browse around, as the book as a whole is not too sure about what it actually has to say. It thus becomes difficult to appreciate the publication independently from the exhibition it was meant to accompany. 